\title{
EXTENSION OF A QUALITATIVE MODEL ON NUTRIENT CYCLING AND TRANSFORMATION TO INCLUDE MICROTIDAL ESTUARIES ON WAVE- DOMINATED COASTS: SOUTHERN HEMISPHERE PERSPECTIVE
}

\author{
S Taljaard*, L van Niekerk and W Joubert \\ CSIR, P O Box 320, Stellenbosch, 7599, South Africa
}

\begin{abstract}
Estuaries are dynamic transition zones acting as filters and transformers of nutrients passing from catchments to the sea. We propose an extension to an existing southern hemisphere model on nutrient dynamics in estuaries to include the relatively constricted, microtidal estuaries located along wave-dominated coasts in the region, specifically focusing on the limiting macronutrients nitrogen $(\mathrm{N})$ and phosphorus $(\mathrm{P})$ and on key processes, including physical (e.g. flushing, mixing and sedimentation), geochemical (e.g. flocculation), biochemical (e.g. remineralisation) and biological (e.g. primary production) processes. A simplified model of the physical states (primarily controlled by hydrological characteristics) is used as the basis for the qualitative model, where these are defined in terms of characteristic salinity-induced stratification of the water column, flushing time and the mouth condition. Four physical states are identified: a freshwater-dominated state, freshwater pulsed/recovery state, marine-dominated state and the closed mouth state. The states and their physical characteristics largely resemble that of the earlier model, except that the extended model reflects the dynamics of restricted inlets and introduces the closed mouth state. This model specifically explores the variation within southern African estuarine systems to better inform research and management programmes on the appropriate trophic, temporal and spatial scales at which uncertainties in ecosystem functioning need resolving. It can also be applied to other regions in the southern hemisphere, and even the northern hemisphere, with similar hydrological and estuarine geomorphological characteristics (e.g. the Mediterranean coast, the west coasts of North and South America, and the south-west and south-eastern coasts of Australia).
\end{abstract}

Key words: mircotidal estuaries, macronutrient cycling, wave-dominated, restricted inlet, qualitative model, southern hemisphere

Corresponding author Tel: +27 21 8882494; Fax: +27 21 882693; e-mail: staljaar@csir.co.za 


\section{Introduction}

Estuaries are important geochemical (e.g. flocculation), biochemical (e.g. remineralisation) and biological (e.g. primary production) 'reactors', filtering and transforming nutrients passing from the catchment (river) to coastal shelf waters (Church, 1986). In their reviews on the nutrient characteristics of South African estuaries, Allanson and Winter (1999) and Allanson (2001) concluded that, with the diversity of estuary types and individual responses to physical and chemical determinants within highly dynamic environments, the need for techniques with which to integrate these features into qualitative and numerical models was becoming essential.

Major distinguishing factors influencing nutrient cycling patterns and storage in estuaries across climatic regions are the timing and magnitude of hydrologic inputs and the ability to trap nutrient loads Eyre, 2000). In the temperate northern hemisphere (e.g. North America and Western Europe) annual runoff is much less variable than, for example, in subtropical and temperate regions of the southern hemisphere, as illustrated by the coefficient of variation of annual flow (Cv) for western European (0.29), North American (0.35), Australian (0.7) and South African (0.7) systems (Braune, 1985; Eyre, 1998). Typically the larger estuaries in the temperate northern hemisphere vary from well-mixed to partially stratified, two-layered systems (usually in spring when runoff increases) (Fisher et al., 1988). These systems receive regular nutrient loading from the catchment (e.g. during spring) and have a high nutrientretention efficiency (i.e. a significant proportion of the nutrient load is trapped and recycled to fuel subsequent production) (Eyre, 2000). In contrast, smaller systems in the southern hemisphere (e.g. Australia and South Africa) can vary from completely flushed freshwaterdominated systems during periods of high runoff to completely marine-dominated systems during periods of low or no river inflow (Largier and Taljaard, 1991; Eyre, 2000; Taljaard et al., 2009). In these systems nutrient loading can be highly variable, while nutrient-retention efficiency is low (Eyre, 2000).

Models describing nutrient dynamics in estuaries have been developed for larger systems in the temperate regions of the northern hemisphere (e.g. North America and Western Europe) (Fisher et al., 1988; Eyre, 1998). However, these models are not necessarily applicable to southern hemisphere systems of South Africa and Australia, primarily due to variability in 
runoff (climatology and hydrology of the southern hemisphere force greater variability in runoff) and geomorphology (catchment and marine sediment availability and geological processes lead to a large number of small, shallow systems compared with the temperate northern hemisphere systems) (Eyre, 1998; Cooper, 2001; Peel et al., 2004).

Although conceptual (or qualitative) models of nutrient dynamics have been proposed for the smaller temporarily open/closed estuaries of South Africa (Snow and Taljaard, 2007; Snow and Adams, 2007; Taljaard et al., 2009), such models have not been developed for the wider spectrum of estuarine types in the region (based on the classification of Whitfield, 1992). Nutrient dynamic models for Australian systems mainly focused on the wet and dry subtropical/tropical estuaries found in northern New South Wales, Queensland, the Northern Territory and northern Western Australia (Eyre and Twigg, 1997; Eyre, 1998; Eyre, 2000; Eyre and Ferguson, 2006). These systems are largely tide-dominated and have less restricted inlets compared with, for example, estuaries along a wave-dominated coast (Turner et al., 2004). Despite the complexity of nutrient processes in estuaries, Eyre $(1998,2000)$ was able to develop a simplified model, primarily linked to different phases of the southern hemisphere region's hydrological regime.

An extension of the above model is presented here to include the relatively sediment-rich, microtidal estuaries that occur along the wave-dominated coast of South Africa. In particular, the model recognises the occurrence of restricted inlets and includes a closed state, i.e. when estuaries are isolated from the sea by the formation of a sand bar across the mouth (Whitfield, 1992; Cooper, 2001). The model identifies the dominant nutrient cycling and transformation processes under different physical states, focusing mainly on the limiting macronutrients $\mathrm{N}$ and $\mathrm{P}$ and key processes, such as physical (e.g. flushing, mixing and sedimentation), geochemical (e.g. flocculation), biochemical (e.g. remineralisation) and biological (e.g. primary production) processes.

Like the original model developed by Eyre $(1998,2000)$, the extended model can be applied to other regions of the world with similar hydrological and geomorphological characteristics, such as the Mediterranean coast (e.g. Palmones, Modego and Tagus estuaries), west coast of north and south America (e.g. Pozuelos-Murillo lagoon system and Elkhorn Slough) and south-west and south-eastern Australia (e.g. Swan and Hopkins river estuaries) (Sharples et 
al., 2003; Hernández-Romero et al., 2004; Avilés and Neill, 2005; Brearly, 2005; Caffrey et al., 2007; Libellø, et al., 2007; Simas and Ferreira, 2007; Robson et al., 2008).

\section{Study Area}

According to Brown and Jarman (1978) the South African coast spans three biogeographical regions (or climatic zones), namely the cool temperate west coast, warm temperate south coast and subtropical east coast (Figure 1). Rainfall patterns in the different regions vary greatly as a result of South Africa's highly variable climate. In the cool temperate region, the climate ranges from semi-arid (extended periods of low to no rainfall interspersed with short flash rain events) along the west coast to Mediterranean (dominated by seasonal winter rainfall) along most of the south-western coast. In the warm temperate region along the south coast, rainfall is largely bi-modal, with peaks in spring and autumn, while the subtropical region along the east coast is dominated by seasonal summer rainfall (Davies and Day, 1998). River inflow to the estuaries is determined by these climatic conditions, as well as the size and shape of the catchment, the latter controlling the magnitude and flow distribution of runoff (Reddering and Rust, 1990). Catchment size varies significantly, ranging from very small (less than $1 \mathrm{~km}^{2}$ ) to very large (greater than $10000 \mathrm{~km}^{2}$ ), with those in the cool temperate region tending to be larger than those in the warm temperate and subtropical regions (Jezewski et al., 1984; Reddering and Rust, 1990).

South Africa's coast is generally characterised by low tidal ranges and high wave energy, making it a wave-dominated coast (Cooper, 2001). The approximately 250 functional estuaries (Whitfield, 1992) are predominantly microtidal systems that are highly dynamic and shallow $(\sim 2-3 \mathrm{~m})$. Owing to strong wave action and high sediment availability, more than $90 \%$ of the estuaries have restricted inlets, with more than $75 \%$ closing for varying periods of time when a sand bar forms across the mouth (Whitfield, 1992). Using a variety of criteria such as catchment size, mouth characteristics and tidal prism, Whitfield (1992) categorised South Africa's estuaries into five types: temporarily open/closed, permanently open, river mouths, estuarine bays and estuarine lakes. Most of these types occur in all three biogeographical regions, apart from estuarine bays and lakes, which are absent from the cool temperate region (Whitfield, 1992). 
Numerous definitions for estuaries have been published (Elliot and McLusky, 2002). The estuary study boundaries in this paper are based on a combination of the definitions proposed by Fairbridge (1980), setting the extent of an estuary as the limit of tidal rise, and Day (1981), recognising that estuaries may not necessarily have a 'free connection with the sea' but are 'either permanently or periodically open to the sea'. The most appropriate definition in this context is as follows: "An estuary is a partially enclosed water body, either permanently or periodically open to the sea, extending as far as the upper limit of tidal rise and usually being divisible into three sectors: (a) a marine or lower estuary; (b) a middle estuary subject to strong salt and freshwater mixing; and (c) an upper or fluvial estuary, characterized by freshwater but subject to strong tidal action. The limits between these sectors are variable and subject to constant changes in the river discharges."

\section{Methods}

Both existing and new empirical data were used to develop the extended model Existing empirical data (salinity and inorganic nutrients data) include that from the Knysna (an estuarine bay situated in the warm temperate region) (Switzer, 2003) and Kromme (a permanently open system in the warm temperate region) (Scharler and Baird, 2000) estuaries (Figure 1). New data were collected from five systems, namely the Keurbooms (a permanently open system in the warm temperate region), the Great Berg (a permanently open system in the cool temperate region), the Breede estuary (a permanently open system in the warm temperate region), the Olifants (a permanently open system in the cool temperate region) and the Great Brak (a temporarily open/closed system in the warm temperate region)

estuaries (Figure 1). Sampling took place during 16-19 March 1987 in the Keurbooms estuary (6 stations, Figure 2a), on 19 September 1989 in the Great Berg estuary (10 stations, see Figure 1, Slinger and Taljaard, 1990), on 23 August 2000 in the Breede estuary (12 stations, Figure 2b), on 2 March 2004 in the Olifants estuary (13 stations, Figure 2c) and on 28 July 2007 in the Great Brak estuary (18 stations, see Figure 1, Slinger et al., 1990). Details on key physical characteristics of the above-mentioned estuaries are provided in Table 1, while Table 2 summarises the type of data (salinity and inorganic nutrients) used from the different systems to develop the model.

Salinity and temperature measurements were taken in situ at 0.25 to $0.5 \mathrm{~m}$ depth intervals along the estuaries using a Valeport MKII CTDS meter (accuracy: salinity 0.2; temperature 
$0.2^{\circ} \mathrm{C}$; depth $0.1 \mathrm{~m}$ ). Salinity was measured on the Practical Salinity Scale. South African estuaries receive relatively limited freshwater inflow, with the result that salinity within systems varies over the entire range from 0 to 35 , whereas temperature seldom varies through a range of more than $10^{\circ} \mathrm{C}$ at any one time. Consequently, salinity is generally the dominant factor in determining stratification (density variations), and is frequently used to describe water circulation patterns (Schumann et al., 1999). Samples for macronutrient analyses, in this case total inorganic nitrogen [dissolved nitrate, nitrite, total ammonia] (DIN) and dissolved reactive phosphate (DRP), were collected from surface and bottom waters in the five systems at the selected stations. Samples were filtered in the field through $0.45-\mu \mathrm{m}$ Millipore filters, stored in polyethylene sampling bottles and frozen until further analyses. A Technicon Auto-analyser II (Seal Analytical, West Sussex, England) (detection limits for dissolved nitrate, nitrite, total ammonium and reactive phosphate: $10 \mu \mathrm{g} \mathrm{l}^{-1}$ ) was used for the analyses according to the methods described in CSIR (2002).

Longitudinal salinity contour plots are used to demonstrate salinity distribution patterns, while mixing diagrams (or property-salinity plots) - widely used to assess water column nutrient dynamics in estuaries (Church, 1986; Eyre, 2000; Eyre and Balls, 1999; Ferguson et al., 2004) - are used to describe inorganic nutrient distribution patterns. Nutrient concentrations are plotted against salinity along the estuarine gradient, providing a convenient method for displaying the net effect of nutrient processes within estuaries. For example, a linear relationship in the mixing diagram typically reflects straight mixing of the two water sources (i.e. the river and the sea), while downward curvature implies in situ nutrient uptake and upward curvature in situ nutrient release (Eyre, 2000; Ferguson et al., 2004). Conservative behaviour tends to occur during high river inflow, when estuaries are rapidly flushed. High nutrient input from the catchment (relative to input from the sea) reveals a negative linear correlation, whereas high input from the sea shows a positive linear correlation. Deviation from the conservative mixing line tends to occur during periods of low or no river inflow, when long flushing times allow in situ processes to have a more significant influence on nutrient dynamics (e.g. remineralisation releasing nutrients into the water column or primary production taking up nutrients from the water column) (Eyre, 2000).

Published literature on salinity and inorganic nutrient distribution patterns on several other systems was also sourced to validate the model design and include the East Kleinemonde (Taljaard et al., 2009), Gamtoos (Snow et al., 2000a), Great Fish (Allanson and Winter, 1991; 
Jennings, 2005), Groen (Bickerton, 1981a), Kariega (Allanson and Winter, 1991; Taylor, 1992; Allanson and Read, 1995), Kromme (Baird and Heymans, 1996; Snow et al., 2000b; van Ballegooyen et al., 2004; Snow and Adams, 2006), Langebaan (Mazure and Branch, 1979; Tibbles et al., 1994), Mdloti (Perissinotto et al., 2004), Palmiet (Largier and Taljaard, 1991), Spoeg (Bickerton, 1981b), Swartkops (Baird and Winter, 1992), Swartvlei (HowardWilliams and Allanson, 1981) and Van Stadens (Gama et al., 2005) estuaries (Figure 1). Key physical characteristics of these estuaries are provided in Table 1.

\section{Assessment of Empirical Data}

The array of salinity and nutrient distribution patterns that occur under different river inflow regimes in microtidal estuaries along a wave-dominated coast (Table 2) is illustrated using results from the Keurbooms, Great Berg, Breede, Olifants, Great Brak, Knysna and Kromme estuaries.

Strong marine influence was evident in the Keurbooms estuary during 16-19 March 1987, when river inflow was low (Figure 3a). Similarly, salinity profiles measured in the Great Berg and Olifants estuaries during dry seasons in January 1990 (Figure 3b, after Slinger and Taljaard, 1994) and March 2004 (Figure 3c), respectively, showed strong marine influence with a gradual horizontal salinity gradient extending along the entire length of the systems. Salinity profiles measured in the Great Berg estuary on 19 September 1989, towards the end of the rainy season, showed strong freshwater influence (Figure 3d). The system was fresh throughout, except in the lower reaches near the mouth, where limited intrusion of seawater occurred during high tides, creating a small but strong horizontal salinity gradient in this area. Salinity profiles collected in the Breede estuary on 23 August 2000 (Figure 3e) reflected a significant pulse of freshwater present in the system, well beyond the head of the estuary. Pronounced stratification occurred towards the middle reaches, with significant seawater influence in the lower reaches. This phenomenon was also evident in the Knysna estuary on 13/14 November 2000 during a small flood (Switzer, 2003). Similarly, a strong freshwater front was created in the Kromme estuary during a water release from a dam (simulating a freshwater pulse) situated just upstream of the estuary in November 1998 (Scharler and Baird, 2000). Salinities in the Great Brak estuary measured on 28 July 2008 (Figure 3f), during a low-flow period and after the system had been closed for 80 days, revealed relatively wellmixed conditions with only a weak salinity gradient along the estuary (salinity $30-25$ ). 
During a low-flow period and strong marine influence in the Keurbooms estuary (16-19 March 1987), $\mathrm{NO}_{\mathrm{x}}-\mathrm{N}$ (nitrate + nitrite, a component of DIN) concentrations in the water column did not show any clear relationship with salinity (Figure 4a). However, mean $\mathrm{NO}_{\mathrm{x}}-\mathrm{N}$ concentrations measured in a shallow 'blind arm' near the mouth (Figures 2a) were significantly higher $\left(241 \mu \mathrm{g} \mathrm{l}^{-1}\right)$ than those measured in the rest of the estuary $\left(86 \mu \mathrm{g} \mathrm{l}^{-1}\right)(t=-$ 3.5; $P<0.001$; d.f. = 35), suggesting that the "blind" arm (with extensive intertidal and subtidal cover of the macrophyte Zostera sp.) was a significant in situ source of $\mathrm{NO}_{\mathrm{x}}-\mathrm{N}$. This trend, however, was not apparent in the DRP data, which remained low throughout the estuary (mean $=13 \mu \mathrm{g} \mathrm{l}^{-1}$; range: 5-32 $\mu \mathrm{g} \mathrm{l}^{-1} ; \mathrm{n}=66$ ) (Figure 5a). Under low flows and strong marine influence, mixing diagrams for DIN in both the Great Berg (31 January 1990) and Olifants (4 March 2004) estuaries indicated downward curvature, suggesting removal of inorganic nitrogen from the water column (Figures $4 \mathrm{~b}$ and 4c, respectively) (Great Berg: exponential; $\mathrm{r}^{2}=0.6 ; \mathrm{n}=51$; Olifants: $2^{\text {nd }}$ order polynomial; $\left.\mathrm{r}^{2}=0.7 ; \mathrm{n}=25\right)$. The mixing diagram for DRP in the Great Berg estuary also showed downward curvature, suggesting removal of this nutrient from the water column (Figure 5b) (exponential; $\mathrm{r}^{2}=0.7 ; \mathrm{n}=51$ ). Mixing diagrams for DRP in the Olifants estuary, however, showed upward curvature, suggesting in situ release of DRP into the water column (Figure $5 \mathrm{c})\left(2^{\text {nd }}\right.$ order polynomial; $\mathrm{r}^{2}$ $=0.8 ; \mathrm{n}=25$ ). At the time, dense submerged macrophyte beds (e.g. Potomageton sp.) were observed in the fresher upper reaches of the Olifants estuary. Towards the end of the rainy season, under freshwater-dominated conditions (19 September 1989), the mixing diagram for DIN in the Great Berg estuary followed the conservative mixing line $\left(\mathrm{r}^{2}=0.8 ; \mathrm{n}=38\right)$ (Figure $5 \mathrm{~d}$ ), with river inflow introducing the highest concentrations. DRP also displayed strong linear correlation with salinity $\left(\mathrm{r}^{2}=0.8 ; \mathrm{n}=38\right)$, except that highest concentrations were introduced from the sea (Figure 5d). In the Breede estuary, when elevated river inflow created a significant freshwater front well beyond the head of the estuary (23 August 2000), DIN concentrations showed a strong linear correlation with salinity $\left(r^{2}=0.95 ; n=23\right)$ (Figure 4e). DRP concentrations were low, revealing no particular relationship with salinity (mean = $20 \mu \mathrm{g} \mathrm{l}^{-1}$; range: $15-28 \mu \mathrm{g} 1^{-1} ; \mathrm{n}=23$ ) (Figure 5e). Likewise, DIN concentrations in the Knysna estuary showed strong linear correlation with salinity $\left(r^{2}=0.8 ; n=44\right)$ during a small flood on 13/14 November 2000 (Figure 4f, after Switzer, 2003). DRP concentrations were generally low with no clear relationship to salinity (median $=25 \mu \mathrm{g} \mathrm{l}^{-1}$; range: $9-186 \mu \mathrm{g} \mathrm{l}^{-1}$; $\mathrm{n}=44$ ) (Figure 5f, after Switzer, 2003). Immediately after a water release (simulating a freshwater pulse) in the Kromme estuary (18 November 1998), the mixing diagram for DIN tended to followed a conservative mixing line $\left(r^{2}=0.6 ; n=43\right)$ (Figure $4 \mathrm{~g}$, after Scharler and 
Baird, 2000). Again, DRP concentrations were low and did not display any clear relationship with salinity $\left(<10 \mu \mathrm{g} \mathrm{l}^{-1}\right.$ ) (Figure 5g, after Scharler and Baird, 2000). A few days after the release (23 November 1998), the mixing diagram for DIN showed downward curvature $\left(2^{\text {nd }}\right.$ order polynomial; $\mathrm{r}^{2}=0.9 ; \mathrm{n}=22$ ) (Figure $5 \mathrm{~h}$, constructed from data presented in Scharler and Baird, 2000), suggesting some removal of DIN from the water column of the estuary. DRP concentrations in the estuary remained low with no particular relationship to salinity $\left(<10 \mu \mathrm{g} \mathrm{l}^{-1}\right.$ ) (Figure 5h, constructed from data presented in Scharler and Baird, 2000). DIN and DRP concentrations measured in the Great Brak estuary on 28 July 2007, during a lowflow period when the system had been closed for about 80 days, were near depleted, with concentrations of both nutrients mostly below the detection limit $\left(<10 \mu \mathrm{g}^{-1}\right)$ (Figures $4 \mathrm{i}$ and 5i).

\section{Development of Extended Qualitative Model}

The assessment of empirical data, as well as other previous assessments of South African systems (e.g. Schumann et al., 1999; Adams et al., 2002; Van Ballegooyen et al., 2004), revealed four characteristic physical states for relatively sediment-rich, wave-dominated, microtidal systems, namely a freshwater-dominated state, freshwater pulsed/recovery state, marine-dominated state and the closed mouth state (Figure 6). These states and their physical characteristics largely resemble those presented in Eyre's model $(1998,2000)$, except that the extended model now reflects the dynamics of restricted inlets and introduces the closed mouth state. Focusing on specific climatic regions (e.g. wet and dry subtropical/tropical), Eyre (1998, 2000) was able to provide 'unique' hydrological descriptors for the different states, namely 'flood phase' (freshwater-dominated state), 'recovery or small flood phase' (freshwater pulsed/recovery state) and 'dry season' (marine-dominated state). With the large variability in climatic conditions (influencing rainfall) and catchment sizes (controlling the magnitude and flow distribution of runoff), such hydrological descriptors are no longer considered appropriate within the South African context. For example, a freshwaterdominated state can occur as a result of a flood (e.g. in estuaries receiving runoff from smaller catchments), as in Eyre's model, but also as a result of extended periods of elevated seasonal high flows (e.g. in estuaries receiving runoff from larger catchments in the seasonal winter rainfall region). Furthermore, in microtidal systems with restricted inlets, a 'dry season' can result in a marine-dominated state as in Eyre's model, but also in a closed mouth state. It was considered more appropriate to use the description of the physical condition in the estuary as 
state descriptors in the extended model. Therefore, although a different naming convention is used, Eyre's $(1998,2000)$ general approach is still applied. Using a simplified model of the physical states (primarily controlled by hydrological characteristics) as the basis for the nutrient cycling and transformation model, states are defined in terms of the characteristic salinity distribution (e.g. position of the freshwater front), water column stratification (e.g. stratified or well-mixed), flushing time and, in this case, the mouth condition (e.g. open or closed).

\subsection{Freshwater-dominated state}

The freshwater-dominated state (Figure 6a) occurs during periods of high river inflow when an estuary is either completely flushed by freshwater (e.g. during floods) or becomes freshwater-dominated on the weaker tides (e.g. seasonal high flows), as observed in the Great Berg estuary during September 1989. This state has also been observed in the Palmiet estuary (a small temporarily open/closed system situated in the cool temperate region) during periods of high (winter) rainfall (Largier and Taljaard, 1991). During this state a pronounced freshwater front is present outside the estuary in the nearshore coastal shelf, occasionally moving into the lower estuary (e.g. during spring flood tides). The location of the front is a function of the size of the estuary, since smaller estuaries are completely flushed more readily than large systems, as well as the volume of river inflow. Flushing times are short, typically ranging from hours to days.

During the freshwater-dominated state, mixing diagrams for water column nutrients (DIN and DRP) typically followed a conservative mixing line, as was observed in the Great Berg estuary (September 1989). This indicates that concentrations are largely determined by the extent of mixing between river (fresh) water (salinity 0) and seawater (salinity 35), and are hence primarily influenced by physical processes. Nutrients entering the estuary from the catchment are flushed out onto the nearshore coastal shelf without any significant transformation happening in the estuary (Figure 7a). As a result of this rapid flushing, biochemical and biological (e.g. phytoplankton production) processes usually have little influence on nutrient transformation in the water column, as was illustrated by the low water column chlorophyll $a$ concentrations measured in the Great Berg estuary at the time (below 3

$\mu \mathrm{g}^{-1}$ ) (Slinger and Taljaard, 1990). In addition, the low light availability associated with high turbidity inhibits primary production by both phytoplankton and benthic microalgae and 
submerged macrophytes. Nutrient fluxes across the intertidal-open water boundary are usually insignificant compared with those being introduced from the catchment. During floods, it can also be expected that sediments and benthic particulate organic matter (and associated nutrients) will be re-suspended in the estuary through scouring, and subsequently transported onto the nearshore coastal shelf (Figure 7a).

\subsection{Freshwater pulsed/Recovery}

This state, as observed in the Breede (23 August 2000), Knysna (13/14 November 2000) and Kromme (November 1998) estuaries, is typical of periods when river inflow is sufficiently elevated to create a pronounced freshwater front well downstream from the estuary head, but with tidal intrusion preventing it from moving outside the system onto the nearshore coastal shelf (Figure 6b). In their study on the Gamtoos estuary (a permanently open system in the warm temperate region), Schumann and Pierce (1997) also observed the formation of this pronounced freshwater front after a freshwater pulse. Density differences at the freshwater front result in marked stratification (longitudinal and/or vertical) and most likely a decrease in turbulence (Eyre, 2000).

Flushing times in the freshwater pulsed/recovery state can range from days to weeks depending on the size and shape of the estuary. Water exchange across the intertidal-open water boundary can be significant depending on the extent of tidal exchange, although exchange may restricted for short periods as the freshwater pulse enters the estuary. This state typically occurs for relatively short periods ('pulse' effect), either as a transition period between the marine-dominated and freshwater-dominated states or when a small flood or freshette introduces a pulse of freshwater into an estuary. However, in the Great Fish estuary (a permanently open system situated in the warm temperate region) the freshwater pulsed state is artificially maintained through an inter-basin transfer supplying additional water to its catchment, perpetuating a pronounced freshwater front and strong stratification for extended periods (Jennings, 2005). This state also occurred in the Thukela estuary (a river mouth situated in the subtropical region) during periods of relatively low river inflow (RSA DWAF, 2004), illustrating that this state can occur during low flows in estuaries with volumes that are small compared to the volume of runoff received from the catchments. 
Conservative mixing lines for DIN measured in the Breede (23 August 2000) and Knysna (13/14 November 2000) estuaries during the onset of the freshwater pulsed/recovery state indicate that water column nutrient concentrations were largely determined by the extent of mixing between river (fresh) water (salinity 0 ) and seawater (salinity $\sim 35$ ). Conservative behaviour was also evident in the mixing diagrams constructed for nitrate- $\mathrm{N}$ for both the Kariega and Fish estuaries (see Allanson and Winter, 1999) at the onset of freshwater pulsed/recovery states. Therefore, as the freshwater pulse is introduced, water column nutrient distribution patterns typically display conservative behaviour, largely influenced by physical processes (e.g. flushing and mixing). However, as this state prevails and the flushing time increases, processes other than flushing and mixing become more significant, for example biological processes (e.g. phytoplankton production), with the result that nutrient distribution patterns become non-conservative (Figure 7b). Many of South African estuaries rely on catchment-derived nutrients to stimulate water column primary production (Snow et al., 2000a; Gama et al., 2005), so when a pronounced freshwater front is introduced to these systems it creates a plug of lingering higher nutrient waters that promote water column primary production. For example, in the Kromme estuary DIN concentrations initially had a strong linear relationship with salinity at the onset of a freshwater pulsed/recovery state (18 November 1998) (i.e. strong conservative behaviour). However, the downward curvature in the DIN mixing diagram from a few days later (23 November 1998) suggests in situ removal of this limiting nutrient by phytoplankton production (Snow et al., 2000b). The increase in water column primary production was short-lived as a result of the rapid depletion of the 'new' nutrient introduced by the freshwater pulse, and low in situ estuarine nutrient supplies (Scharler and Baird, 2000). Interestingly, subtidal benthic primary production did not increase significantly, attributed to pronounced stratification that prevented the nutrient-rich surface waters introduced by river inflow from reaching the sediments (Snow et al., 2000b; Snow and Adams, 2006).

During this state, strong salinity, $\mathrm{pH}$ and other physico-chemical gradients near the freshwater front increase the potential effects of geochemical processes such as adsorption/desorption and flocculation, contributing to the removal of sediment, organic matter and associated inorganic nutrients (Eyre and Twigg, 1997; Nielsen et al, 2001). The lower turbulence in the vicinity of the freshwater front allows catchment-derived sediment and organic matter to settle from the water column, the extent of deposition depending on factors such as land-use and catchment geology, the timing and size of the flow event, particle size, current velocities, 
and the position of the freshwater front, which is primarily influenced by river inflow and the tidal phase. This state is therefore important in supplying potential nutrients, or 'food stores', to the estuary to be utilised in subsequent states, e.g. a marine-dominated state (Eyre and Twigg, 1997). Allanson and Read (1995) proposed that the salinity gradient at freshwater fronts, coupled with the phenomenon of hydrodynamic trapping, the flocculation of suspended matter and the availability of nutrients, provides the stimulus for water column production and, ultimately, defines the richness of the phytoplankton and zooplankton stocks in microtidal estuaries. For example, during a freshwater pulsed state in the Thukela estuary phytoplankton concentrations peaked in the middle reaches, coinciding with the position of the freshwater front, with highest concentrations at water depths between 0.5 and $2 \mathrm{~m}$ (chlorophyll a $\sim 120 \mu \mathrm{g} \mathrm{l}^{-1}$ ) (RSA DWAF, 2004). Although benthic biogeochemical and biological processes may well be significant in terms of nutrient cycling and transformation in sediments, these processes are not considered to have a marked affect on water column nutrients during the freshwater pulsed/recovery state because flushing times remain relatively short. During this state the role of intertidal areas in nutrient dynamics may become significant where extended tidal inundation of such areas occurs. However, it is expected that the effect of fluxes across the intertidal-open water boundary may still be masked by the (stronger) catchment fluxes, particularly towards the fresher middle and upper reaches of the estuary This cannot be confirmed for microtidal estuaries in the region due to the lack of data, and needs further investigation

\subsection{Marine-dominated state}

The marine-dominated state typically occurs during periods of low or no freshwater inflow and where the estuary mouth remains open (due to limited sediment input and sufficient tidal exchange), allowing seawater to penetrate upstream as observed in the Keurbooms (March 1989), Great Berg (31 January 1990) and Olifants (4 March 2004) estuaries. Large estuarine bays such as the Knysna estuary predominantly function as marine-dominated systems, with a small freshwater front present only in the extreme upper reaches (Largier et al., 2000). A horizontal salinity gradient is usually present in the estuary with a weak freshwater front situated towards the upper reaches, depending on the extent of river inflow (Figure 6c). Limited vertical stratification may exist in the vicinity of the front. In the larger systems flushing times in the middle and upper reaches may be long (weeks to months), whereas stronger tidal exchange results in much shorter flushing times in the lower reaches (hours to 
days). In the smaller systems tidal exchange may even be able to maintain short flushing times for the entire estuary depending, on the state of the mouth and tide.

In extreme cases of the marine-dominated state, estuaries can become completely saline or even hypersaline (salinity greater than 35). This is typical of estuaries where sediment input is limited and the tidal exchange is strong enough to maintain an open mouth even when there is no river inflow, as in the Kromme estuary (van Ballegooyen et al., 2004). Here hypersaline conditions developed as a result of extended periods of no freshwater inflow combined with high evaporation rates. The extreme marine-dominated state has also been observed in the Kariega estuary (a permanently open system in the warm temperate region), where Jennings (2005) showed that the system became hypersaline in the upper reaches during a dry period (June). Tidal exchange, which is largely a function of the state of the tide and mouth dimensions (width and depth), plays a major role in the extent of water exchange across the intertidal-open water boundary within an estuary during the marine-dominated state.

Mixing diagrams for DIN measured in the both the Olifants (4 March 2004) and Great Berg (31 January 1990) estuaries showed downward curvature during marine-dominated states, suggesting in situ removal of water column nutrients with only limited renewal from the catchment in the upper reaches (salinity less than 5) and tidal intrusion near the mouth (salinity greater than 30). In the Kromme estuary, water column DIN and DRP concentrations also became near depleted (less than $50 \mu \mathrm{g} \mathrm{l}^{-1}$ and less than $10 \mu \mathrm{g} \mathrm{l}^{-1}$, respectively) during this state (Scharler and Baird, 2000). Here the standing stock of bacteria and microzooplankton, and possibly also organic matter, was considered too low to provide sufficient quantities of recycled nutrients to the water column in the absence of nutrient supplied through river inflow. This was supported by the low phytoplankton productivity measured in the estuary during marine-dominated states on other occasions (Baird and Heymans, 1996; Snow et al., 2000b). In the Kariega estuary, Allanson and Winter (1999) also observed that the sea became the only potential source of new nitrate- $\mathrm{N}$ to the system during periods of low or no river inflow. Therefore, when river inflow decreases and the external nutrient supplies are limited, these shallow microtidal systems are unable to support significant water column primary production once nutrient stocks in the water column have been depleted. Primary productivity by benthic microalgae and rooted macrophytes then becomes dominant, as was observed in the Kariega (Allanson and Read, 1995) and Knysna (Switzer, 2003) estuaries. Switzer (2003) argued that such benthic processing zones play an 
important role as nutrient sinks in enriched systems, and the destruction of such zones (e.g. as a result of coastal development) will result in an increased nutrient load to the water column, and hence eutrophication. However, excessive enrichment of systems can also deviate from this expected regime of dominant benthic primary productivity with low river inflow, as in the case of the Gamtoos estuary, where agricultural return flow introduces persistently high nutrient loads, maintaining high water column phytoplankton production even during periods of low river inflow (Snow et al., 2000a).

In larger systems, long flushing times and low current velocities characteristic of the fresher upper reaches during the marine-dominated state can favour the development of large beds of submerged macrophytes (e.g. Potomageton sp.) that influence nutrient cycling, as was observed in the Olifants estuary (January 1990). Upward curvature in the DRP mixing diagram suggested an in situ source of this nutrient, attributed to foliar release by the Potomageton sp. known to supply DRP to estuarine waters (McRoy et al., 1972; Adams et al., 1999). This is contrary to Howard-Williams and Allanson's (1981) findings in the Swartvlei (a coastal lake in the warm temperate region), where the exchange of DRP between Potamogeton sp. beds located in the littoral zone and the open waters of the estuary was low, which they attributed to rapid nutrient recycling within the littoral zone. However, the Potomageton sp. beds in the Olifants estuary were exceptionally dense as a result of artificial nutrient enrichment $(\mathrm{N})$ from fertiliser introduced in the catchment. These dense beds probably generated DRP through foliar release at faster rates than could be assimilated by new growth, as was the case in a more natural situation (e.g. Swartvlei).

Where tidal exchange is significant, the sea becomes an important source of new nutrients to estuaries (especially DIN) during the marine-dominated state, particularly in systems adjacent to coastal upwelling cells. However, rapid water exchange (short flushing times) in the lower reaches probably prevents this nutrient source from being utilised effectively by water column primary producers (e.g. phytoplankton), and it is largely submerged macrophytes and intertidal communities (e.g. salt marsh) that benefit (Taylor, 1992; Scharler and Baird, 2000). In the Kariega estuary tidal nutrient inputs associated with upwelling were significant, having a marked impact on the flux of DIN to intertidal saltmarsh areas (Sarcocornia perennis and Chenolea diffusa), even increasing biological uptake rates in the marsh (Taylor, 1992). 
During this state, tidal exchange can influence nutrient exchange across the intertidal-open water boundary within the estuary, depending on factors such as the size of the intertidal area and the extent and energy of tidal intrusion (Figure 7c), as observed in the Keurbooms estuary (16-19 March 1987). Here, remineralisation/nitrification associated with macrophyte litter in the extensive Zostera beds within a shallow blind arm provided a significant source of $\mathrm{NO}_{\mathrm{x}}-\mathrm{N}$ for the open waters of the lower reaches. Hence, the large variety of vegetation types in southern African estuaries, including macroalgae, submerged macrophytes, reeds and sedges, saltmarsh and mangroves (Adams et al., 1999, Steinke, 1999; Adams et al., 2004), also play an important role in nutrient cycling and transformation (Valiela et al., 1978; Lee, 1995). Studies in the Langebaan Lagoon (a estuarine bay in the cool temperate region receiving mostly groundwater input) showed that colonisation of macrophyte (Zostera capensis) litter by $\mathrm{N}$-fixing bacteria increased the $\mathrm{N}$ content of this litter, which was an important source of new N to the system (Tibbles et al., 1994; Mazure and Branch, 1979). However, in the Swartkops estuary (a permanently open system in the warm temperate region), nutrient fluxes between an intertidal marsh (Spartina maritima) and the open waters of the estuary were small, since the marsh retained and utilised most of its own production, virtually functioning as an independent ecosystem (Baird and Winter, 1992). Therefore, depending on the dominant vegetation, intertidal areas can act either as sinks or sources of nutrients.

Although river inflow and the sea can still influence the nutrient characteristics within an estuary during the marine-dominated state, longer flushing times and more stable sediments generally create conditions favourable for biochemical and biological processes to contribute significantly to nutrient cycling and transformation, particularly in the middle and upper reaches (although wind-mixing may reduce sediment stability in shallower areas) (Figure 7c). However, during this state the importance of different nutrient cycling and transformation processes is strongly linked to site-specific conditions that should be considered when assessing the extent of the different processes for a particular estuary. For example, in smaller systems effective tidal exchange is able to maintain short flushing times throughout the estuary, and processes requiring longer flushing times may not be as relevant.

\subsection{Closed mouth state}

During periods of little or no river inflow, relatively sediment-rich and wave-dominated microtidal estuaries can become isolated from the sea by the formation of a sand bar across 
the mouth, as observed in the Great Brak estuary (28 July 2007). Flushing times (or lack thereof) depend on the duration of closure, which can range from days to years. In small, shallow systems the closed mouth state eventually reverts to a well-mixed (due to wind turbulence) brackish system, with no distinct salinity gradient or stratification (Figure 6d). If the low-flow periods coincide with periods of high evaporation, estuaries can become more saline, or even hypersaline, a condition observed in systems receiving runoff from catchments in the semi-arid areas in the cool temperate region, e.g. the Groen and Spoeg estuaries (Bickerton, 1981a \& 1981b). Alternately, systems where river inflow is balanced by seepage to the sea through the sand bar can become increasingly fresh, which is typical of estuaries along the east coast of South Africa with lower evaporation rates during the low-flow periods (Perissinotto et al., 2004; Snow and Taljaard, 2007). For example, the Mdloti estuary (a small temporarily open-closed estuary in the subtropical region and typical of many small systems in this region) is generally closed during low-flow periods (winter) (Perissinotto et al., 2004), but seldom becomes marine-dominated because the mouth is perched (limiting tidal exchange) and the wave action and sediment supply along the adjacent coast is high (requiring significant river inflow to maintain an open mouth) (Perissinotto et al., 2004). For the same reason, such estuaries can close while still in the freshwater pulsed/recovery state, i.e. with a pronounced freshwater front still present in the estuary (Perissinotto et al., 2004). In estuaries that do not have perched mouths, or where the mouth areas are not subject to continuous high wave action (e.g. in the cool and warm temperate regions), the closed mouth state is normally preceded by the marine-dominated state (e.g. Great Brak estuary) (CSIR, 1998). A number of small perched estuaries along the South African coast also display variations of the closed mouth state, namely the 'semi-closed state' and 'over-wash of seawater' (Van Niekerk et al., 2002). These variations on the closed mouth state are discussed in greater detail in Snow and Taljaard (2007). With no tidal exchange during the closed mouth state, water exchange across the intertidal-open water boundary within the estuary is limited.

Nutrient cycling and transformation processes during a closed mouth state can vary considerably depending on the period of closure. Limited water exchange, together with stable sediments, creates favourable conditions for biochemical and biological processes to have a potentially significant influence on nutrient cycling and transformation throughout the estuary (Figure 5d). For example, in the Great Brak estuary DIN and DRP concentrations were near-depleted after 80 days of closure (28 July 2007), indicating significant removal of 
water column nutrients. Although benthic-pelagic coupling (e.g. sediment remineralisation providing nutrients for water column primary production) cannot be excluded, it is argued that most South African systems lack sufficient sediment organic matter stocks to support largescale water column primary productivity through benthic-pelagic coupling, except perhaps in anthropogenically enriched estuaries (Taljaard et al., 2009). The rationale here is that the smaller, shallow systems (e.g. the East Kleinemonde estuary, a small temporarily open/closed system in the warm temperate region) can be effective flushed (or re-set) of accumulated organic matter during seasonal high flows, in contrast with larger, deeper and wider estuaries that will require much higher river inflows for effective flushing, resulting in a build-up of benthic organic matter (benthic total organic matter recorded in the East Kleinemonde estuary was $0.7 \mathrm{mg} . \mathrm{g}^{-1}$ [Taljaard et al., 2008]). During the closed mouth state, benthic biochemical processes (e.g. remineralisation and $\mathrm{N}$-fixation) are, however, still important in terms of supporting benthic biological processes (e.g. benthic microalgal production and macrophyte growth). Where closure occurs soon after a freshwater pulse, dominant nutrient cycling and transformation processes may show stronger resemblance to those occurring in the freshwater pulsed/recovery state at the onset. For example, the Mdloti estuary often closes while the influence of a strong freshwater pulse is still evident in the system, so the nutrients introduced from the catchment are retained for a sufficiently long time to stimulate significant water column primary production (Perissinotto et al., 2004). However, low DIN and DRP concentrations measured in the water column on occasions when the mouth had been closed for some time also suggest that these small and shallow microtidal systems are unable to support significant water column primary production once nutrient stocks in the water column have been depleted, although benthic production may be significant. The latter is reflected in higher DIN and DRP concentrations measured in the interstitial water of the sediments of the Mdloti estuary at the time (compared with a freshwater-dominated state), which was attributed to benthic remineralisation becoming more dominant after closure (Perissinotto et al., 2004). Benthic microalgal production was also greater during the closed mouth state, owing to stable sediments and greater benthic nutrient availability.

In the semi-closed state (i.e. when there is an outflow, but no tidal exchange), estuaries receive a continuous, low supply of (river-derived) nutrients that may be retained sufficiently long to stimulate water column production (Snow and Taljaard, 2007). Therefore, in the semi-closed state, water column productivity can sustain a marked influence on nutrient cycling and transformation, as long as the system remains in the semi-closed state. During the 
closed state, 'overwash' can also introduce nutrient-rich coastal waters (e.g. the result of upwelling), albeit limited to the lower reaches near the mouth. Here higher nutrient availability, together with sufficient residence time, can stimulate water column primary production in the form of phytoplankton or macroalgal blooms in the lower reaches, as observed in the Van Stadens estuary (a small temporarily open/closed system in the warm temperate region), where a peak in phytoplankton production occurred after an overwash event (Gama et al., 2005).

Although nutrient exchange across the intertidal-open water boundary is expected to be low, extended periods of inundation (caused by raised water levels during the closed state as a result of limited freshwater inflow or seawater overwash) can result in die-back of the intertidal vegetation. This may subsequently become a significant source of organic matter to the estuary and adjacent coastal ecosystems when tidal exchange is re-established, or when the system is flushed (Adams and Bate, 1994; Adams et al., 1999).

\section{Concluding Remarks}

An extension to an existing southern hemisphere model on nutrient dynamics in estuarine systems (Eyre, 1998 and 2000) was presented here so as to include the relatively constricted, microtidal estuaries located along wave-dominated coasts in the region, largely based on the knowledge and understanding of the temperate and subtropical systems in South Africa. Similar to Eyre's $(1998,2000)$ general approach, a simplified model of the physical states (primarily controlled by hydrological characteristics) was used as the basis for the qualitative model on nutrient cycling and transformation, where the states were defined in terms of characteristic salinity distribution (e.g. position of the freshwater front), water column stratification (e.g. stratified or well-mixed), flushing time and the mouth condition (e.g. open or closed). The model specifically focused on the limiting macronutrients nitrogen $(\mathrm{N})$ and phosphorus (P) and on key processes, including physical (e.g. flushing, mixing and sedimentation), geochemical (e.g. flocculation), biochemical (e.g. remineralisation) and biological (e.g. primary production) processes.

Although the different states can potentially occur in all wave-dominated, microtidal estuaries (depending on the river inflow regime), current understanding suggests that some states tend to occur more frequently in specific estuarine types (based on Whitfield's classification, 
1992). The estimated frequency of occurrence and distribution of the various states for specific estuarine types are shown in Table 3. The range of river inflow volumes corresponding to each of the states is site-specific and will depend on characteristics such as the size and shape (bathymetry) of the estuary, tidal exchange, and other physical factors controlling the dimensions (depth and width) of the mouth. Therefore, to establish the typical seasonal frequency distributions of states within a particular system it is necessary to define the relationship between the river inflow and individual states, taking into account the sitespecific physical characteristics of the estuary in question. Further refinements to the model include the possibility of differentiating between models for estuaries dominated by different vegetation types, e.g. the salt marsh-dominated systems of the temperate regions versus the mangrove-dominated systems of the subtropical regions.

The model explores the variation within southern African systems to better inform research and management programmes on the appropriate trophic, temporal and spatial scales at which uncertainties in ecosystem functioning need resolving. As with the original model (Eyre, 1998 and 2000), this extended model can be applied to other regions in the southern hemisphere - and even the northern hemisphere - with similar hydrological and geomorphological characteristics, such as the Mediterranean coast (e.g. Palmones, Modego and Tagus estuaries), west coast of north and south America (e.g. Pozuelos-Murillo lagoon system and Elkhorn Slough) and south-west and south-eastern Australia (e.g. Swan and Hopkins river estuaries) (Sharples et al., 2003 ; Hernández-Romero et al., 2004; Avilés and Neill, 2005; Brearly, 2005; Caffrey et al., 2007; Libellø et al., 2007; Simas and Ferreira, 2007; Robson et al., 2008).

\section{Acknowledgements}

Some of the data and information used in this paper were collected as part of ecological water requirement determination studies and research projects commissioned by the South African Department of Water Affairs and Forestry and the Water Research Commission of South Africa.

Constructive contributions by the journal reviewers and our colleagues, Patrick Morant and Alan Meyer, are much appreciated. 


\section{References}

Adams, J.B. and Bate, G.C., 1994. The effect of salinity and inundation on the estuarine macrophyte Sarcocornia perennis (Mill.) A.J. Scott. Aquatic Botany 47: 341-348.

Adams, J.B., Bate, G.C. and O'Callaghan, M., 1999. Chapter 5: Primary producers: Estuarine microalgae and Estuarine macrophytes. In: Estuaries of South Africa. Allanson, B R \& Baird, D (Eds.). Cambridge University Press, p 91- 118.

Adams, J.B., Bate, G.C., Harrison, T.D., Huizinga, P., Taljaard, S., Van Niekerk, L., Plumstead, E.E., Whitfield, A.K., and Wooldridge, T.H., 2002. A Method to Assess the Freshwater Inflow Requirements of Estuaries and Application to the Mtata Estuary, South Africa. Estuaries 25(6B):1382-1393.

Adams, J.B., Colloty, B.M. and Bate, G.C., 2004. The distribution and state of mangroves along the coast of Transkei, Eastern Cape Province, South Africa. Wetlands Ecology and Management 12: 531-541.

Allanson, B.R. and Read, G.H.L., 1995. Further comment on the response of Eastern Cape Province estuaries to variable freshwater inflows. South African Journal of Aquatic Science 21: $56-70$.

Allanson, B.R. and Winter, P.E.D., 1999. Chemistry. In: Allanson BR and Baird D (eds.) Estuaries of South Africa. Cambridge Univ. Press. pp 53-90.

Allanson, B.R., 2001. Some factors governing the water quality of microtidal estuaries in South Africa. Water SA 27 (3): 373-386.

Avilés, A. and Niell, F.X., 2005. Pattern of phosphorus forms in a Mediterranean shallow estuary: Effects of flooding events. Estuarine, Coastal and Shelf Science 64: 786-794.

Baird, D. and Heymans, J.J., 1996. Assessment of ecosystem changes in response to freshwater inflow of the Kromme River Estuary, St. Francis Bay, South Africa: A network analysis approach. Water SA 22(4): 307-318. 
Baird, D. and Winter, P.E.D., 1992. Flux of inorganic nutrients and particulate carbon between a Spartina maritima salt marsh and the Swartkops Estuary, Eastern Cape. South African Journal of Aquatic Science 18(1/2): 64-73.

Balls, P.W., 1994. Nutrient inputs to estuaries from nine Scottish east coast rivers; influence of estuarine processes on inputs to the North Sea. Estuarine, coastal and shelf science 39: 329-352.

Bickerton, I.B., 1981a. Estuaries of the Cape. Part II. Synopses of available information on individual systems. Report no. 3. Groen (CW7). Heydorn, A.E.F and Morant, P.D. (Eds.). CSIR Research Report 401. Stellenbosch, South Africa. 40 pp.

Bickerton, I.B., 1981b. Estuaries of the Cape. Part II. Synopses of available information on individual systems. Report no. 1. Spoeg (CW5). Heydorn, A.E.F and Morant, P.D. (Eds.). CSIR Research Report 400. Stellenbosch, South Africa. 28 pp.

Braune, E. 1985. Aridity and hydrological characteristics: Chariman's summary. Hydrobiologia 125: 131-136.

Brearly, A. 2005. Ernest Hodgkin's Swanland: Estuaries and coastal lagoons of Southwestern Australia. University of Western Australia Press. 550 pp.

Brown, A.C and Jarman, N. 1978. Coastal marine habitats. Chapter 8 in Biogeography and Ecology of Southern Africa. Wiener, M.J.A. (Ed.). W. Junk, The Hague. Pp 1239-1277.

Caffrey, J.M., Chapin, T.P., Jannasch, H.W. and Haskins, J.C., 2007. High nutrient pulses, tidal mixing and biological response in a small California estuary: Variability in nutrient concentrations from decadal to hourly time scales. Estuarine, Coastal and Shelf Science 71: 368-380.

Church, T.M., 1986. Biogeochemical factors influencing the residence time of microconstituents in a large tidal estuary, Delware Bay. Marine Chemistry 18: 393-406. 
Cooper J.A.G., 2001. Geomorphological variability among microtidal estuaries from the wave-dominated South African coast. Geomorphology 40 : 99-122.

Council for Scientific and Industrial Research (CSIR), 1998. Great Brak management programme. Interim Report. Report on the monitoring results for the period April 1997 to March 1998. CSIR Report ENV/S-C 98122. Stellenbosch, South Africa. 22 pp.

Cowan, G.I., 1995. Section 1.1: South Africa and the Ramsar Convention. In: Wetlands of South Africa. Cowan, G. I. (Ed.). South African Wetlands Conservation Programme Series. Department on Environmental Affairs and Tourism, Pretoria, South Africa. pp 1-31.

CSIR, 2002. Analytical Methods Manual. Estuarine and marine waters, sediment and biological tissue. CSIR Technical Report ENV/S-I 97011. Stellenbosch, South Africa. 133 pp.

Davies, B. and Day, J., 1998. Vanishing Waters. University of Cape Town Press, Cape Town, South Africa. 487 pp.

Day, J. H. (Ed.), 1981 Estuarine ecology with particular reference to Southern Africa. A.A. Balkema, Cape Town, South Africa. 411 pp.

Elliott, E. and McLusky, D.S. 2002. The need for definitions in understanding estuaries. Estuarine, Coastal and Shelf Science 55: 815-827.

Eyre, B., 1998. Transport, retention and transformation of material in Australian estuaries. Estuaries 21 (4A): 540-551.

Eyre, B., 2000. Regional evaluation of nutrient transformation and phytoplankton growth in nine river-dominated subtropical east Australian estuaries. Marine Ecology Progress Series 205: 61-83.

Eyre, B. and Balls, P., 1999. A comparative study of nutrient behaviour along the salinity gradient of tropical and temperate estuaries. Estuaries 22 (2A): 313-326. 
Eyre, B. and Ferguson, A.J.P., 2006. Impact of a flood event on benthic and pelagic coupling in a subtropical east Australian estuary (Brunswick). Estuarine, Coastal and Shelf Science 66: 111- 122 .

Eyre, B. and Twigg, C., 1997. Nutrient behaviour during post-flood recovery of the Richmond river estuary Northern NSW, Australia. Estuarine, Coastal and Shelf Science 44: 311-326.

Fairbridge, R.W. 1980 The estuary: its definition and geochemical role. In: Chemistry and Geochemistry of Estuaries (Olausson, E. and Cato, I., eds). John Wiley, New York, pp. 1-35.

Ferguson, A., Eyre, B. and Ga, J., 2004. Nutrient cycling in the subtropical Brunswick Estuary, Australia. Estuaries 27 (1): 1-17.

Fisher, T.R., Harding, L.W. Jr., Stanley, D.W. and Ward, L.G., 1988. Phytoplankton, nutrients and turbidity in the Chesapeake, Delaware and Hudson estuaries. Estuarine, Coastal and Shelf Science 27(1): 61-93.

Gama, P.T., Adams, J.B., Schael, D.M. and Skinner, T., 2005. Phytoplankton chlorophyll a concentration and community structure of two temporarily open/closed estuaries. Water Research Commission Report No. 1255/1/05. Pretoria, South Africa. 91 pp.

Heinecken, T.J.E., 1981. Estuaries of the Cape. Part II. Synopses of available information on individual systems. Report no. 2. Buffels (CW3). Heydorn, A.E.F and Morant, P.D. (Eds.). CSIR Research Report 401. Stellenbosch, South Africa. 32 pp.

Hernández-Romero, A.H., Tovilla-Hernández, C., Malo, E.A. and Bello-Mendoza, R., 2004. Water quality and presence of pesticides in a tropical coastal wetland in southern Mexico. Marine Pollution Bulletin 48: 1130-1141.

Howard-Williams, C. and Allanson, B.R., 1981. Phosphorus cycling in dense Potamageton pectinatus L. beds. Ocealogia (Berl) 49:56-66. 
Jennings, M.E., 2005. Nutrient dynamics in and offshore of two permanently open South African Estuaries with contrasting fresh water inflow. M.Sc., Rhodes University, Grahamstown. 155pp.

Jezewski, W.A., Pyke, P.D. and Roberts, C.P.R., 1984. Estuarine and Lake Freshwater Requirements, Technical Report No TR123, Deaprtment of Water Affairs and Forestry, Pretoria, South Africa.

Lillebø, A.I., Coelho, J.P., Flindt, M.R., Jensen, H.S, Marques, J.C., Pedersen, C.B, and Pardal, M.A., 2007. Spartina maritima influence on the dynamics of the phosphorus sedimentary cycle in a warm temperate estuary (Mondego estuary, Portugal). Hydrobiologia 587:195-204.

Largier, J.L. and Taljaard, S., 1991. The dynamics of tidal intrusion, retention, and removal of seawater in a bar-built estuary. Estuarine, Coastal and Shelf Science 33: 325-338.

Largier, J.L., Attwood, G. and Harcourt-Baldwin, J-L., 2000. The hydrographic character of the Knysna Estuary. Transaction of the Royal Society of South Africa 55(2): 107-122.

Mazure, H.G.F. and Branch, G.M., 1979. A preliminary assessment of bacterial numbers and biomass in the Langebaan Lagoon. Transactions of the Royal Society of South Africa. 44: 4354.

McRoy, C.P., Barsdate, R.J. and Nebet, M., 1972. Phosphorous cycling in an eelgrass (Zostera marina L.) system. Limnology and Oceanography 17(1): 58-67.

Nielsen, K., Risgaard-Petersen, N., Sømod, B., Rysgaard, S. and Bergø, T., 2001. Nitrogen and phosphorus retention by flux measurements and dynamic modelling in the estuary, Randers Fjord, Denmark. Marine Ecology Progress Series 219: 25-40.

Peel, M. C., McMahon, T.A. and Finlayson, B.L., 2004. Continental differences in the variability of annual runoff- update and reassessment. Journal of Hydrology 295: 185-197. 
Perissinotto, R., Blair, A., Connell, A., Demetriades, N.T., Forbes, A.T., Harrison, T.D., Iyer, K., Joubert, M., Kibirige, I., Mundree, S., Simpson, H., Stretch, D., Thomas, C., Thwala, X. and Zietsman, I., 2004. Contributions to information requirements for the implementation of Resource Directed Measures for estuaries. Volume 2: Responses of the biological communities to flow variation and mouth state in two Kwazulu-Natal temporarily open / closed estuaries. Report to the Water Research Commission by the Consortium for Estuarine Research and Management. WRC Report No. 1247/2/04. Pretoria, South Africa. 166 pp.

Reddering, J.S.V. and Rust, I.C., 1990. Historical changes and sedimentary characteristics of southern African estuaries. South African Journal of Science 86: 425-428.

Robson, B.J., Bukaveckas, P.A. and Hamilton, D.P., 2008. Modelling and mass balance assessments of nutrient retention in a seasonally-flowing estuary (Swan River Estuary, Western Australia). Estuarine, Coastal and Shelf Science 76: 282-292.

Republic of South Africa, Department of Water Affairs and Forestry (RSA DWAF), 2004. Thukela Water Project Decision Support Phase. Reserve Determination Model. Volume 1 Appendices to Thukela Estuarine Flow Requirements. PBV000-00-10308. Directorate of National Water Resource Planning, Pretoria, South Africa. 84 pp.

Schumann, E.H., and Pearce, M.W., 1997. Freshwater inflow and estuarine variability in the Gamtoos Estuary, South Africa. Estuaries 20(1): 124-133

Schumann, E.H., Largier, J.L. and Slinger, J.H., 1999. Chapter 3: Estuarine hydrodynamics. In: Estuaries of South Africa. Allanson, B R \& Baird, D (Eds.). Cambridge University Press, p. 27-90.

Scharler, U.M. and Baird, D., 2000. The effect of a single freshwater release into the Kromme Estuary. Part 1: General description of the study area and physico-chemical responses. Water SA 26(3): 291-300.

Sharples, J., Coates, M.J. and Sherwood, J.E., 2003. Quantifying turbulent mixing and oxygen fluxes in a Mediterranean-type, microtidal estuary. Ocean Dynamics 53: 126-136. 
Simas, T.C. and Ferreira, J.G., 2007. Nutrient enrichment and the role of salt marshes in the Tagus estuary (Portugal). Estuarine, Coastal and Shelf Science 75: 393-407.

Slinger, J.H. and Taljaard, S., 1990. Preliminary investigation of seasonality in the Great Berg Estuary. Water SA 20(4): 279-287.

Slinger, J.H., Taljaard, S. and Largier, J.L., 1990. Changes in estuarine water quality in response to a freshwater flow event. In: Changes in Fluxes in Estuaries. Dyer, K.R and Orth, R.J. (Eds.). ECSA22/ERF Symposium. International Symposium Series. Olsen and Olsen, Denmark, p 51-54.

Snow, G.C., Adams, J.B. and Bate, G.C., 2000a. Effect of river flow on estuarine microalgal biomass and distribution. Estuarine, Coastal and Shelf Science 51: 255-266.

Snow, G.C., Bate, G.C. and Adams, J.B., 2000b. The effects of a single freshwater release on the Kromme Estuary. 2: Microalgae response. Water SA 26(3): 301-310.

Snow, G.C. and Adams, J.B., 2006. Response of micro-algae in the Kromme Estuary to managed freshwater inputs. Water SA 32(1): 71-80.

Snow, G.C. and Taljaard, S., 2007. Water quality in South African temporarily open/closed estuaries: A conceptual model. African Journal of Aquatic Science 2007, 32 (2): 99-111.

Snow, G.C. and Adams, J.B., 2007. Relating microalgal spatial patterns to flow, mouth and nutrient status in the temporarily open/closed Mngazi estuary, South Africa. Marine and Freshwater Research 58: 1032-1043.

Steinke, T.D., 1999. Chapter 6: Mangroves in South African estuaries. In: Estuaries of South Africa. Allanson, B R and Baird, D (Eds.). Cambridge University Press, p 119-140.

Switzer, T, B., 2003. The role of water column and benthic communities in the spatial and temporal production and uptake of nutrients in controlling the trophic status of the Knysna River Estuary, South Africa. Thesis Presented for the Degree of Doctor of Philosophy, Department of Oceanography, University of Cape Town, South Africa. 184 pp plus appendices. 
Taljaard, S., Gama, P. T., and Snow, G. C. 2008. Appendix E. Specialist Report: Water Quality. In 'An Intermediate Ecological Reserve Determination Study of the East Kleinemonde Estuary'. (Eds L. van Niekerk, G. C. Bate and A. K. Whitfield.) Water Research Commission Report 1581/2/08. Water Research Commission, Pretoria, South Africa.

Taljaard, S., Snow, G.C., Gama, P. and van Niekerk, L., 2009. Verification of a conceptual model of water quality for small temporarily open/closed estuaries: East Kleinemonde Estuary, South Africa. Marine and Freshwater Research 60: 234-245.

Taylor, D.I., 1992. The influence of upwelling and short-term changes in concentrations of nutrients in the water column on fluxes across the surface of a salt marsh. Estuaries 15(1): 6874.

Tibbles, B.J., Lucas, M.I., Coyne, V.E. and Newton, S.T., 1994. Nitrogenase activity in marine sediments from a temperate saltmarsh lagoon: modulation by complex polysaccharides, ammonium and oxygen. Journal of Experimental Biology and Ecology 184: $1-20$.

Turner, L., Tracey, D., Tilden, J. and Dennison, W.C., 2004. Where river meets sea: Exploring Australia's estuaries. Published by the Cooperative Research Centre for Coastal Zone, Estuary and Waterway Management (Coastal CRC), Queensland, Australia. 278 pp.

Van Ballegooyen R.C, Taljaard, S., Van Niekerk, L. and Huizinga P., 2004. Using 3DModelling to predict physico-chemical responses to variation in river inflow in smaller, stratified estuaries typical of South Africa. Journal of Hydraulic Research 42 (6): 563-577.

Van Niekerk, L., Huizinga P. and Theron, A. 2002. Semi-closed mouth states in estuaries along the South African coastline. In: Environmental Flows For River Systems Proceedings. Fourth International Ecohydraulics Symposium, Cape Town.

Whitfield, A.K., 1992. A characterisation of southern African estuarine systems. Southern African Journal of Aquatic Sciences 12: 89-103. 
Whitfield, A.K., Adams, J.B., Bate, G.C., Bezuidenhout, K., Bornman, T.G., Cowley, P.D., Froneman, P.W., Gama, P.T., James, N.C., Mackenzie, B., Riddin, T., Snow, G.C., Strydom, N.A., Taljaard, S., Terörde, A.I., Theron, A.K., Turpie, J.K., van Niekerk, L. Vorwerk. P.D. and Wooldridge, T.H., 2008. A multidisciplinary study of a small, temporarily open/closed South African estuary, with particular emphasis on the influence of mouth state on the ecology of the system. African Journal of Marine Science 30(3): 453-473.

\section{Figure Captions}

Figure 1: Distribution of biogeographical regions along the South African coast as well as locations of estuaries discussed

Figure 2: Sampling stations in the a) Keurbooms, b) Breede and c) Olifants estuaries

Figure 3: Salinity distribution patterns measured in the a) Berg Estuary (19 September 1989), b) Breede Estuary (23 August 2000), c) Berg Estuary (31 January 1990), d) Olifants Estuary (2 March 2004), e) Keurbooms Estuary 16-19 March 1987) and f) Great Brak Estuary (28 July 2008)

Figure 4: Mixing diagrams for DIN (unless otherwise indicated) for a) Great Berg Estuary (19 September 1989), b) Breede Estuary (23 August 2000), c) Knysna Estuary (13/14 November 2000, d) Kromme Estuary (18 November 1998), e) Kromme Estuary (23 November 1998), f) Great Berg Estuary (31 January 1990), g) Olifants Estuary (4 March 2004), h) Keurbooms Estuary (16-19 March 1987) and i) Great Brak Estuary (28 July 2008)

Figure 5: Mixing diagrams for DRP (unless otherwise indicated) for a) Great Berg Estuary (19 September 1989), b) Breede Estuary (23 August 2000), c) Knysna Estuary (13/14 November 2000, d) Kromme Estuary (18 November 1998), e) Kromme Estuary (23 November 1998), f) Great Berg Estuary (31 January 1990), g) Olifants Estuary (4 March 2004), h) Keurbooms Estuary (16-19 March 1987) and i) Great Brak Estuary (28 July 2008) 
Figure 6: Qualitative model of the different physical states common to South African estuaries a) freshwater-dominated, b) freshwater pulsed/recovery, c) marinedominate and d) closed mouth (modified from Eyre, 1998 and 2000)

Figure 7: Qualitative model of dominant nutrient cycling and transformation processes during a) a freshwater-dominated state, b) freshwater pulsed/recovery state, c) marine-dominated state and d) closed mouth state (modified from Eyre, 1998 and 2000)

\section{Table Captions}

TABLE 1: Specific details on estuaries used as case studies (Bickerton, 1981; Heinecken, 1981; Jezewski et al., 1984; Allanson and Read, 1995; Cowan, 1995; Whitfield and Wood, 2003; Turpie, 2004; Whitfield et al., 2008)

TABLE 2: Summary of empirical data and information used in the development of the model from the different estuaries

TABLE 3: Apparent distribution of the occurrence of various physical state in each of the five estuarine types within the cool temperate, warm temperate and subtropical regions (as classified by Whitfield, 1992) 